\title{
The main factors of successful project management in the aspect of energy enterprises' efficiency in the digital economy environment
}

ABSTRACT: At present, it is said that Industry 4.0 is the fourth industrial revolution. Like the previous ones, it also has the ability to transform economies, jobs and societies. Our expectations are changing to the speed of obtaining answers to the questions asked. This is done by introducing new technologies and processes. This is an opportunity for Polish participants of local heat markets, or participants of the power or energy market. who are currently facing profound changes and investments forced, among others, by BAT conclusions. Such mega-processes as digitization, automation, artificial intelligence, IoT, machine learning are increasingly penetrating the world and business. More than 200 years have passed since the first industrial revolution, which was the use of the steam engine, and the requirements for testing the efficiency of enterprises have changed, which themselves are changing very quickly. The basic efficiency measures used in a given sector often result from the specifics of the sector and its degree of development on a macroeconomic scale. Therefore, it is worth placing the energy company in this environment and presenting its role to better match the instruments used. The above is also associated with increased reporting and the need to use additional evaluation measures, e.g. effectiveness of individual projects. It is therefore worth analyzing

$\triangle$ Corresponding Author: Grzegorz Kinelski; e-mail: grzegorz.kinelski@gmail.com

1 Akademia WSB, Dąbrowa Górnicza, Poland; ORCID iD: 0000-0002-5768-463X; e-mail: grzegorz.kinelski@ gmail.com

2020. The Author(s). This is an open-access article distributed under the terms of the Creative Commons Attribution-ShareAlike International License (CC BY-SA 4.0, http://creativecommons.org/licenses/by-sa/4.0/), which permits use, distribution, and reproduction in any medium, provided that the Article is properly cited. 
the available literature in this area, and the performance measures available and used in it, which will help in assessing the effectiveness of management, despite political and regulatory turmoil, and help us use the opportunities brought by the fourth industrial revolution.

KEYWORDS: project management, economic efficiency, digital economy, energy efficiency

\section{Introduction}

Project management, in the understanding of processes taking place in energy enterprises, tackles many key issues for the company. One of them is the measurement of effectiveness. Business performance measures should be considered based on the company's goals. This includes the goals which it intends to achieve in the short as well as in the long term. The above becomes dependent on the time of the analysis. These goals change depending on the environment, currently the digital economy or Industry 4.0 (Miśkiewicz 2017) is a very demanding one which forces the continuous adjustment of objectives, i.e. increased and continuous measurement of indices, including performance indicators. This is an opportunity for Polish participants of local heat markets, or participants of the power or energy market, who are currently facing deep changes and investments forced, among others, by opening markets, connecting markets, changes in the balancing market and BAT conclusions. Such mega-processes as digitization, automation, robotization and artificial intelligence supporting them, IoT (Internet of Things), machine learning are increasingly penetrating the business world and the power sub-sector. The production of heat or energy changes with technological progress. Production technologies as well as measurement technologies and accuracy are changing, including measurements of production efficiency indicators. The technological progress shows that the management of energy production or transmission management is changing more than the production technologies themselves (Zamasz 2019). It is also worth remembering that the current phase of innovation and inventiveness is taking place as part of sustainable development (Szczepańska-Woszczyna and Kurowska-Pysz 2016). To learn about these changes and choose the methodology for measuring effectiveness effectively in the current environment, it is worth exploring the next ranges of industrial revolutions. This is what we call the industrial use of great inventions.

In this context the main aim of the paper is to analyze the possibilities, relationships, solutions and efficiency measures available and used in energy companies, which may be helpful to assess the effectiveness of management, despite political and regulatory turmoil, and also in order to better use the opportunities offered by the fourth industrial revolution.

The present time is the next, ongoing fourth industrial revolution. It is the use of communication and information technologies in industry. It is often referred to as the "Digital Economy" or "Industry 4.0" (Tarafdar et al. 2017). Fully computerized production systems are additionally equipped with network connections and their digital systems are created, real-time models, in- 
formation is collected in clouds. This enables communication with other objects and the transfer of information about the devices themselves, their condition, consumption, speed of work, necessary changes. Networking all systems leads to the creation of "smart" factories. These processes are controlled by cognitive technologies, commonly known as artificial intelligence, including neural networks, which will be discussed in the next chapter of the article.

\section{Development of management practices in the field of measuring efficiency and the development of Industry 4.0}

The literature on the subject in the area of efficiency does not present a unified position in determining the purpose of enterprises. One can even distinguish different approaches to this issue in the light of different theories (Skrzypek 2007).

For the owner of an enterprise, economic efficiency, increasing their profits, is the key. It is defined as the difference between the results and the expenses incurred to obtain them. However, not only the owner or the main shareholder is interested in increasing profits. It is in the interest of all stakeholders related to the enterprise, including managers and employees, but also suppliers. Therefore, the measures and levels of economic efficiency of an enterprise are of interest to both internal and external stakeholders. Therefore, there is a reason to be guided by economic efficiency in making decisions in enterprises. This is a condition for their survival and development, and for maximizing the benefits for their owners (Wrzosek 2005). New technologies, and in principle the priority of their implementation, can also contribute to increasing profits. Digitization or robotization can give priority in implementing new products and market flexibility.

These technologies in popular magazines are called artificial intelligence. Nowadays, basic needs in business operations still refer, among others to increase the efficiency of their functioning. This has a significant impact on the desire to maximize profitability in the short term and increase the value of the company in the long term (Pająk 2016). The differences in the applied performance indicators in various sub-sectors of the economy often result from the specificity of the environment of the given sub-sector and its degree of development on a macroeconomic scale. The article discusses issues of efficiency and competitiveness management in the power subsector, in the environment of the digital economy. This era is currently called the Digital Economy or Industry 4.0. These concepts determine the modern directions of changes and opportunities for the economy. Therefore, it is worth placing an energy company in this environment and presenting its role to better match the efficiency management instruments used. Attempts are made in the literature to structure the implementation of artificial intelligence (Kasperski 2003). It is believed, among others, that artificial intelligence has four recognizable implementation waves: Internet, business, perceptive and autonomous (Lee 2019). According to the author, the first two waves already surround us in our daily lives - mobility, digitization and facilitation of shopping, 
financial analyses and medical diagnoses. The next wave, i.e. perceptive digitizing of our current surrounding world. Artificial intelligence in this phase learns to recognize objects, as well as our faces, our emotions and our commands. The last of the phases, the autonomous phase, will appear last and will most affect our lives. Autonomous cars, drones and agricultural machinery will change our economy and the structure of our, as a human, participation in creating GDP.

Concepts such as artificial intelligence, artificial neuron or neural networks are used interchangeably in cognitive technologies, and their origins date back to the first algorithm proposed by McCulloch and Pitts (Belda 2012) in the 1940s. An artificial neuron is just a reflection of this algorithm. These technologies, based on artificial neuron structures, are currently used in various sectors of the economy of leading countries of the world, mainly in the space, military and medicine sectors. Neural networks are special computational structures. They are modeled on biological neuron networks and perceptrons, including the Adaline model discussed in this article, are created in such models (Kurzyński 2008).

For the considerations in this article, this means that if the stimulus, which is the sum of products and weights, results from the decomposition of basic data, exceeds a certain threshold, then activates the neuron (Rutkowski 2012). So we are looking for solutions always closer to the purpose of the search. This will maximize the quality of the prediction of subsequent results, and by building a network based even on this type of simple neurons, we can expect results of sufficient quality (Kasperski 2003).

What is an artificial intelligence or, more generally, cognitive technology? Artificial intelligence (abbreviated AI) is defined by Webster's Dictionary as a "branch of computer science that simulates intelligent behavior in computers" (Merriam-Webster 2019). The Oxford Dictionary explains this basic definition by calling it "computer theory and development systems capable of performing tasks normally requiring human intelligence, such as visual perception, speech recognition, decision making and translation between languages" (Oxford Dictionaries 2019).

Artificial intelligence is mainly about increasing the ability of computers to match or transcend human intelligence in its various forms, by imitating the human ability to discover, reason, and conclude (Nowak-Nova 2018).

Until now, there was a close correlation between the tendency to computerization and automation, and the performance of simple, manual tasks. Such activities were most often replaced by IT systems and robots. It has been observed for several years that automation and algorithmizing increasingly penetrate mental activities. Until recently, such tasks were only in the area of human activities, such as reasoning, sensing and making decisions (Brynjolfsson and McAfee 2014).

The energy subsector is increasingly strategic for the national economy. It is regulated at the national and European level, specifically conditioned on the competitive market. From the research point of view, enterprises of this subsector are economic entities whose functioning and development is based on a number of complex exogenous and endogenous factors (Pająk et al. 2017). The former are economic, political and social. They are complemented by internal ones, such as: company security, organization of basic and ancillary activities, contacts with the environment, and finally exchange and provision of services within the organization, where the environment of the digital economy becomes important. It should be noted that the 
basic efficiency measures used in a given sector often result from its specificity and degree of development on a macroeconomic scale.

The question becomes justified: What factors influence the competitiveness and efficiency of energy sector enterprises in the era of the digital economy? They should be considered in a comprehensive approach, also taking into account their interrelationships and interdependencies.

Technologies based on cognitive processes (Kasperski 2003) are currently considered as strategic investments in many enterprises. It can be assumed that they will soon become so common that they will affect most processes, not only in industrial enterprises (Rutkowski 2012). It is not excluded that this will start with the improvement of already existing processes, and then to their replacement with completely new, much more effective ones. A revolution is coming, where much higher efficiency will be expected, with less and less human resources involved. The surprising growth dynamics of these solutions can be found in the IBM report from 2017 (IBM Developer 2017), which shows that in 2014, the total value of the artificial intelligence market in the world is USD 2.5 billion, currently in 2019 the market for such solutions is worth USD 12.5 billion, and in 2025, it will be worth about USD 180 billion (IBM 2019a).

What is machine learning? Machine learning is the foundation of artificial intelligence and computer science. Machine learning has its roots in statistics and mathematical optimization. Machine learning includes both supervised and unsupervised learning techniques. We use them mainly for forecasting, as well as in data analysis and mining (Jones 2017). Machine learning can (and often is) be used independently of other AI or cognitive technologies. In fact, this is the most common type of artificial intelligence we can observe today. Many machine learning algorithms and techniques are already used in various solutions that look for patterns or anomalies in the data. To structure the concepts and interrelationships, the structure shown in the figure below was developed (Fig. 1).

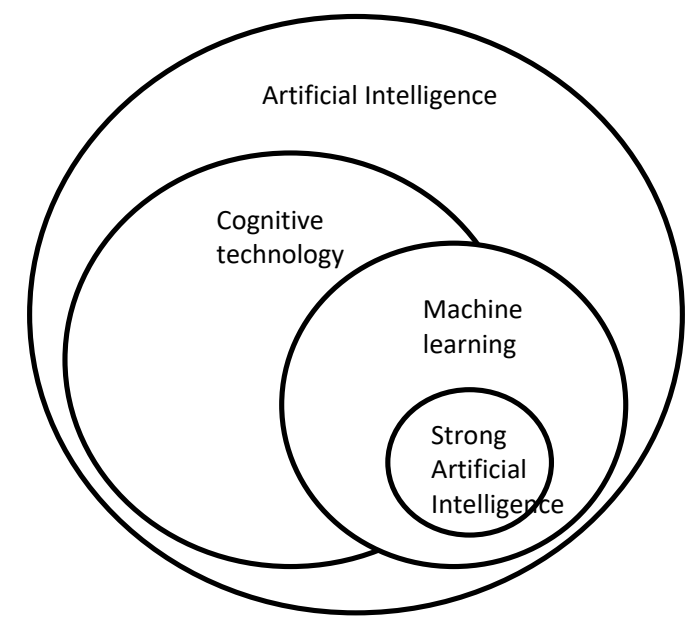

Fig. 1. Diagram of the concept structures and their interrelationships in the field of Artificial Intelligence Source: own elaboration based on IBM materials (IBM 2019b)

Rys. 1. Schemat struktur pojęciowych i ich wzajemnych zależności w obszarze sztucznej inteligencji 
As a result of the development of "learning" or "learning further self-teaching" of computers or robots, they were given the ability to replicate and map human actions and almost feelings and behaviors. Therefore, automation processes can include not only repetitive, routine activities. Not only are individual tasks automated, but also entire processes, and often the variability of these processes is automatic and is not programmed in advance. In recent years, significant progress has been made in the development of Cognitive Systems (CS). This is not about semantics and logic, but about imitating human thinking in the strict sense. The result is that we extract the intelligent one from all automation. Such intelligent processes are not only subject to routine tasks requiring only physical activity, but more importantly, also tasks previously reserved for people, based on understanding. Mainly those tasks that have the nature of intellectual work. The benefits we can achieve thanks to cognitive technologies depend mainly on the type of system we use (Kasperski 2003). This also applies to those activities in which activities can be performed quickly and efficiently by computers that are susceptible to intelligent algorithmizing, e.g. tasks related to supporting decision-making, expertise, forecasting, as well as administrative services, calculating, collecting and processing data.

At present, we should use specialized multidimensional systems and simulation systems for purposes related to enterprise management, its processes, results, efficiency or competitiveness.

Deep machine learning (Rutkowski 2012) is a relatively new set of methods that fundamentally changes machine learning towards greater cognitive capabilities. Deep learning is not in itself an algorithm, but rather a family of algorithms. These algorithms couple wide networks (e.g. neural networks) with unattended learning, i.e. with unattended machine learning algorithms. Deep learning has significant potential for a certain class of problem solving, but it is not suitable for all situations, it is difficult, expensive and time consuming.

It can be seen in our environment that computers, which in some way register the surrounding reality, understand it better and better. This does not apply only to new types of sensors, sensitive to smell, and for example feelings. Based on these advanced analyses, these intelligent machines draw new conclusions and learn. Cognitive solutions are different from other new technologies. They have a unique distinguishing feature. It is the execution of commands that until now could only be carried out by humans.

Thanks to machine learning, as discussed above, computers have gained the ability to recognize images and interpret speech, and even mood or feelings. At present, their efficiency is already high. However, we can expect that at the current pace of development, the gap between man and machine will soon decrease significantly.

cognitive processing is an important element of artificial intelligence. Cognitive computing is the basis of artificial intelligence, which is based on neural networks and deep learning. They use the knowledge of cognitive science to build systems that simulate human thought processes. Instead of focusing on a single set of technologies, however, cognitive processing involves several disciplines, including machine learning, natural language processing, vision, and human-computer interaction. Cognitive processing currently focuses mostly on processing natural language as well as the emotions contained in it. Cognitive computing is artificial intelligence technology, but there are other aspects of artificial intelligence that do not include 
cognitive function. Deep learning is a special type of machine learning. Cognitive computers use both of these elements.

Artificial intelligence in the form of functioning cognitive technologies is used in manufacturing companies. It currently plays an important role in the analysis of data provided by sensors, for example: the Internet of Things. Additionally, the use of special harmonic variable analyzers in power grids and the analysis of such a data stream gives broad possibilities in the detection and identification of specific faults in the field of energy parameters of the device. This can often be detected before the entire machine is damaged and the production process is halted.

Cognitive technologies often disappear from our view and are treated as ordinary data processing. This is what happens, for example, with speech recognition. We use this solution on a daily basis, so we no longer consider it artificial intelligence. Learning networks, including: Markov models (Walsh 2018) and deep-learning networks, are something that we do not think about every day, but use.

Referring to the possibility of using cognitive technologies to assess indicators relating to enterprise products, the parameters most often taken into account are as follows: offers in mobile technologies, quality of services, price, diversity of offered products and services, product and service compatibility, flexibility in adapting services to the needs of recipients. In addition, automation, computerization, higher frequency of introducing new services, good access to services, product range, advertising and sales promotion. Also in the scope of services: scope of pre-sales and after-sales services, prices of after-sales products and services, quality of after-sales services, conditions and warranty period, company image and brand.

Some researchers of cognitive technologies and artificial intelligence have adopted a set of basic definitions of the word 'pattern' that are fairly consistent with the definitions used by scientists in other fields (e.g. 'numerical taxonomy', 'behavioral psychology', 'theoretical linguistics') (Jackson 2019). Definitions are not very difficult to understand, although the word "pattern" is usually not defined in most current scientific considerations. It is worth discussing its use in Al research and discussing some of the general problems associated with "formulas".

New mega-processes in enterprises such as digitization, automation, artificial intelligence, IoT, machine learning is increasingly penetrating the world and business. Over 200 years have passed since the first industrial revolution, which was the use of a steam engine, and the requirements for testing the efficiency of enterprises have changed as well.

The above is also associated with accelerated reporting and the need to use additional evaluation measures, e.g. current efficiency or the effectiveness of individual projects. Therefore, it is worth analyzing available and used efficiency measures and competitiveness factors, taking the possibility of using cognitive technologies for their calculation into account. 


\section{Project management and success factors in making changes}

The term 'Project' or 'Project Management' used in everyday corporate communication is a ubiquitous term. The project, in most definitions, is called, written down our intentions, plans, described technologies and solutions, and finally the project is an organized enterprise with a specific start, end, goal, budget and time frame. It happens that the ambiguity of this term causes inaccuracies and misinterpretation of the concept. For the purposes of this trend analysis, let us assume that the above is the most relevant, and in this context will be used later in the article.

Innovation and technology help energy companies in project management. They enter all its areas. The development of solutions such as Artificial Intelligence and cognitive science allows you to accelerate and simplify processes.

However, the more complicated we create machines, programs, processes, the more they fail. The same happens in projects. The more stakeholders, the more differences of opinion and views. The more you create in the enterprise, project phases, steps, the more complicated our final product is, the more we are exposed to surprising events. This means that running projects, even with the use of modern technologies, will never become tedious. It will not become boring in even 10 or 20 years. Why? Is an energy company significantly different from average enterprises operating in other sectors of the economy?

The differences in the applied project management methodologies in various subsectors of the economy in relation to energy often result from the specificity of the environment of the given subsector and its degree of development on a macroeconomic scale. Therefore, it is worth considering the issues of future project management in the energy sector, in the environment of the digital economy. Currently, this era, popularly called Industry 4.0, defines modern trends of change and opportunities that the economy has thanks to the development of information technology. Therefore, it is worth placing an energy company in this environment and presenting its role to better match the applied project management instruments.

Project managers may encounter problems with meeting deadlines and thus reduce efficiency because they often try to assign tasks to team members rather than broader areas of responsibility. This is due to the belief that a highly structured form of management is preferred in project management, and they ignore the need to provide team members with a larger task.

Trends indicate that individual members and experts will need more freedom and independence in projects. This is due to the increasing scope and complexity of the projects discussed above.

These trends are also reinforced by new methodologies of project management, such as Agile. Agile methodology (PMI 2017) is an iterative approach, narrowing the goal along with work on achieving it. It is a total change in project management, also changing the way of thinking about an end in itself. It is not he who becomes the most important, time and costs, prototyping and quick introduction of even incomplete products to the market in order to improve them later. Many companies have believed that it is better to provide an incomplete prototype quickly than to implement the ideal solution in a controlled and slow manner. 
In many cases hybrid solutions are used and will be used, thus combining Agile with a cascade approach. The next step will probably be management with a smooth scope, a liquid budget and a consistent time, and the project agile periods will last one day or less.

Historically, mega-processes, processes, subprocesses, procedures for describing and measuring them are now the domain of the organization. The design era has now begun. The process will be just one $\operatorname{cog}$ in the organizational machine called the project. The project is quickly changing, but the environment in which it operates is slowly changing. The ability to find a compromise is mainly the communication skills of all participants in the project. A good project communication plan is also crucial.

\section{Effectiveness and competitiveness as trend indicators in project management}

As discussed above, Industry 4.0 includes using cloud solutions to manage organizations. It is an indication for the implementation of many changes in the field of: strategy changes, supply chain transformations, preparation of staff or investment-friendly factors. EU integration, having both an economic and political dimension, played a large role in the restructuring of the Polish energy sector. This process, above all, was determined by the adaptation of the Polish economy to EU requirements, harmonizing Polish legislation with European Union law and ensuring equal, compared to other Member States, pace of introduction of competition, e.g. in the energy sector (Kinelski and Pająk 2017).

Therefore, enterprises from the energy sector face a big challenge of improving the efficiency of their activities. This is directly related to the financial situation, impending lack of liquidity, exceeded covenants for loans, debt to income ratios that are higher than acceptable. There are many opportunities in this area related to their restructuring, consolidation and selection of investment areas. On the one hand, Industry 4.0 requires significant investment outlays to be in the main stream of changes in the digital economy, while on the other it allows for significant cost reduction.

Enterprise performance measures should be considered based on the company's objectives. Performance management using the opportunities of the digital economy provides companies with the opportunity to develop and build a market position. Professional project management can greatly simplify the implementation of changes. Project management is a dynamic process, it requires the support of the entire organization, all participants, even if they do not participate as team members or experts. This environment, if it is open to new ideas, supports development, guarantees that projects will be successful.

Currently, cost reduction, a flexible need for human resources and access to unique competences at a specific moment leads to the intensification of pressure and is causing a flood of remote teams. On the other hand, the development of communication technologies will result 
in the greater efficiency of these teams, and thus a decrease in communication costs over any geographical distance. Probably all the studies on the future of project management maintain the thesis about the very possible development of their remote management. The future definitely belongs to remote teams. It is a kind of cascade-agile hybrid, taking the fact of communication restrictions in a geographically dispersed team into account.

\section{Energy efficiency measures and directions of development of these measures}

Measures of effectiveness in the operation of enterprises are one of the key issues undertaken by researchers in the field of economics and management sciences. Efficiency provides companies with the opportunity to develop and build a market position, which is a key condition for achieving other goals such as capital appreciation, product development, innovation, maximizing managerial benefits and increasing market value so significantly.

Efficiency as a concept in economic terms is itself a subject of measurement. Of course, using indicator analysis methods. He systematized the indicators used in literature (Copeland et al. 1990), distinguishing three groups from them (Jaki 2012):

$\checkmark$ accounting indicators, based on liabilities and assets,

$\checkmark$ financial ratios based on cash flows,

$\downarrow$ market indicators. based on changes in the environment.

Accounting indicators are the most common indicators used to measure effectiveness in ratio analysis (Wilczyński 2014). They treat efficiency directly as a relationship only between revenues and expenses. These indicators mainly measure profitability at various levels of the financial result. In addition, they can find the relationship between profitability and the size of capital employed in an enterprise and the value of its assets.

The next group of effectiveness measures are the financial indicators used. They are based on one main measurement parameter. It's financial flows. They eliminate imperfections of accounting indicators. This mainly applies to the application of different accounting principles. In addition, it also eliminates difficulties in the area of asset and liability valuation methods.

Described selected indicators, for example NPV, DCF, IRR type, are mainly used to assess investment profitability. They try to estimate the future, so the results of such an assessment are always risky. Energy companies also use these indicators to evaluate projects such as new energy investments, e.g. new wind sources, photovoltaics or distributed generation. To minimize the risk, professional paths are used to change ingredients such as Energy Prices, Property Rights Prices, Emission Rights Prices, and Fuel Prices. Such ready paths are provided by analysts, e.g. REDPOint from Baringa's Energy Advisory (BEA 2018).

The next group of indicators are market indicators. They also allow you to assess the company's effectiveness, mainly from the perspective of external stakeholders. The market valuation 
of equity, in this case, always takes past financial results into account. It also takes the current situation and predictions about the future of the company into account. The valuation of shares in an energy company may already be strongly influenced by the degree of computerization or process automation in a manufacturing company. Although, such a valuation can be considered the most objective, it should not be forgotten that the price of shares is not just based on the value of capital.

Market indicators are widely used to assess effectiveness. Thanks to the absolute ratios, which can easily be compared, the analysis becomes attractive for comparative studies in practical terms. In this assessment, there is a market background in the form of invested capital.

Expected changes resulting from the environment of the digital economy require the use of new varieties of performance indicators.

Surrounded by new communication and automation technologies, we can measure multiple parameters simultaneously and provide results in real time. It is worth giving examples that can be used for further scientific development:

$\checkmark$ the production efficiency index per information unit, or its inverse,

$\checkmark$ indicator of the efficiency of computing power involvement per unit of net energy produced,

$\downarrow$ failure efficiency ratio for communication networks and control systems,

$\downarrow$ indicator of the efficiency of the use of database resources per unit of produced or consumed energy,

$\checkmark$ indicator of the effectiveness of decisions of automation systems and artificial intelligence,

$\checkmark$ indicator of the effectiveness of information acquisition in the field of machine learning,

$\checkmark$ the process efficiency indicator can also be defined in the future as the ratio of digital to ana$\log$ technologies used,

$\downarrow$ indicator of the efficiency of using cloud computing resources to produce energy units,

$\downarrow$ process and resource sharing efficiency indicator.

Such considerations, of course, should be supported by the usefulness and need to analyze specific quantities, but it can be assumed that most of them in the near future will become important for the efficiency of manufacturing enterprises.

\section{Summary}

Negative changes in the economic situation may affect the deterioration of operating conditions for enterprises. The desire to make a profit, of course, still does not decrease, but digital technologies, including cognitive processes, are gaining more importance. Until recently, the basic goal of the company was survival, now it is development, which until now stood in second place. In addition to expanding markets, development is just new technologies.

The main condition for survival was to maintain financial liquidity, and the factor determining this liquidity is the efficiency of operating activities (Wilczyński 2014). However, currently 
the main condition for development is keeping up with changing technologies and their skillful use.

Innovation and technology help energy companies to manage their projects. They cover all areas of its functioning. The development of solutions such as Artificial Intelligence and cognitive science allow to accelerate and simplify processes. As a result, projects can be carried out in accordance with the schedule, without exceeding the previously set budgets. Energy companies face also a major challenge related to the efficiency of their operations improvement. This can be directly connected with the financial situation of a particular company.

In the current research, the indicators for assessing efficiency cover only selected goals of the enterprises' functioning. They pay too little attention to operational efficiency, speed of processes, digitization, process efficiency and financial liquidity as key factors in the development of enterprises. In addition, they have a limited scope, because a significant number of indicators (accounting, financial, market) require information that is difficult to access or obtain in large periods of time. Data is obtained quarterly or annually. At the present time, the dynamic development of information technologies and the need to use more information to calculate indicators, the time to obtain results also plays an increasingly important role. To analyze the present using cognitive technologies, we need access to online data. The same applies to future predictions. It is not excluded that we will soon be using quantum technology to measure process efficiency.

This specific combination of the analogue and digital world creates a digital enterprise. An enterprise that is not only connected to artificial intelligence, but also capable of more holistic, conscious decision making. Perhaps even to make decisions or suggest solutions.

The impact of the digital economy on the energy market, power market and heat market is inevitable (Zamasz 2015). For a comprehensive analysis of the effectiveness of an enterprise, appropriate indicators should be selected depending on the degree of achievement of objectives, especially in the era of the digital economy. In addition, the adoption of modern relative indicators will allow for the comparability of results between different enterprises. The analysis of the huge amount of data from devices and sensors in real time gives us the key information needed to manage the company. Acquiring them online allows you to teach cognitive processes. In a digital enterprise, data collected from systems and machines is used to intelligently and more effectively manage the operation of an organization. As a result of these changes, new products and services, more attractive ways of customer service, new professions and completely new business models are developing, in a way.

An analytically desirable situation will include in the calculation of indicators of information not only included in the financial statements of enterprises, but also information received in real time from the inside of production and service processes. The challenge for the economy, including the energy sector, is to change the way of thinking and to learn how to use our exponential technology development to create value for our organization. Although today the hypothetical efficiency indicator, e.g. speed of access to information in the cloud per unit of heat energy produced, seems to be useless, it may soon prove to be a very helpful tool, e.g. in distributed generation networks or virtual power plants. We can therefore use cognitive technologies for fast-changing data that are basically obtained in all energy processes in the energy sector. 


\section{References}

BEA 2018. REDPOint - A consulting project from the British consulting company Baringa's Energy Advisory (REDPOint - projekt doradczy z brytyjskiej firmy doradczej Baringa's Energy Advisory). [Online] http://www.baringa.com/redpoint-energy/\# [Accessed: 01.02.2018].

BELDA, I. 2012. Mind, machines and mathematics. Artificial intelligence and the challenges it faces. RBA Collecionables S.A., Barcelona Hiszpania, pp. 151.

Brynjolfsson, E. and McAfee, A. 2014. The Second Machine Age: Work, Progress, and Prosperity in a Time of Brilliant Technologies. New York: W.W. Norton \& Company.

Copeland et al. 1990 - Copeland, T., Coler, T. and Murrin, J. 1990. Valuation: Measuring and Managing the Value of Companies. $1^{\text {st }}$ ed., New York: John Wiley\&Sons Inc., pp. 145-149.

IBM Developer 2017. [Online] https://ibm.com/investor/att/pdf/IBM_Annual Report_2017.pdf [Accessed:2019-03-21].

IBM 2019a. The cognitive advantage global market report. [Online] https://www.ibm.com/watson/advantage-reports/market-report.html [Accessed: 10.11.2019].

IBM 2019b. Security and Artificial Intelligence: FAQ. [Online] https://www.ibm.com/downloads/cas/ ZQROXRBK [Accessed: 12.11.2019].

JACKSON, P.C. Jr. 2019. Introduction to Artificial Intelligence. New York: Dover Publication Inc., 170 pp.

JAKI, A. 2012. Mechanisms of the Process of Value-based Management (Mechanizmy procesu zarzadzania wartością przedsiębiorstwa). Zeszyty Naukowe nr 215, Seria Specjalna, Monografie, Kraków: Wydawnictwo Uniwersytetu Ekonomicznego w Krakowie, 149 pp. (in Polish).

LeE, K-F. 2019. Ai Superpowers China, Silicon Valley, And The New World Order (Inteligencja Sztuczna Rewolucja Prawdziwa. Chiny, USA i przyszłość świata). Wyd. Media R., Poznań, 132 pp. (in Polish).

KASPERSKI, M.J. 2003. Artificial Intelligence - The path to thinking machines (Sztuczna inteligencja - Droga do myślacych maszyn). Wydawnictwo Helion, Gliwice, 244 pp. (in Polish).

KINELSKI, G. and PAJĄK, K. 2017. Competitive market and sources of its advantages in the electric energy subsector (Rynek konkurencyjny i źródla jego przewagi w subsektorze elektroenergetycznym). Progress in Economic Sciences 4, pp. 347-360.

KURZYŃSKI, M. 2008. Artificial intelligence methods for engineers (Metody sztucznej inteligencji dla inżynierów). Seria wydawnicza PWSZ, Legnica, 122 pp. (in Polish).

Jones, M.T. 2017. A Beginner's Guide to Artificial Intelligence, Machine Learning and Cognitive Computing, [Online] https://www.ibm.com/developerworks/library/cc-beginner-guide- machine-learning-aicognitive/cc-beginner-guide-machine-learning-ai-cognitive-pdf.pdf [Accessed: 12.10.2019].

Merriam-Webster 2019. [Online] https://www.merriam-webster.com/dictionary/artificial\%20intelligence [Accessed:19.08.2019].

MiśKiewicz, R. 2017. Organisational structure in the progress of integration. Munich Personal RePEc Archive, [Online] https://mpra.ub.uni-muenchen.de/81767/ MPRA Paper No. 81767 [Accessed: 21.03.2019].

NowaK-Nova, D. 2018. The potential of cognitive robotization of advanced business processes. Myth or reality? (Potencjat kognitywnej robotyzacji zaawansowanych procesów biznesowych. Mit czy rzeczywistość?) Przedsiębiorczość i Zarządzanie Vol. XIX, Iss. 5, part II,Wydawnictwo SAN, pp. 163-176 [Online] https://www.depot.ceon.pl/bitstream/handle/123456789/16983/Potencjał\%20kognitywnej\%20robotyzacji\%20zaawansowanych\%20procesów\%20biznesowych.pdf?sequence=1\&isAllowed=y [Accessed: 10.08.2019] (in Polish).

Oxford Dictionaries 2019. [Online] https://en.oxforddictionaries.com/definition/artificial_intelligence [Accessed: 11.09.2019]. 
Pająk et al. 2017 - Pająk, K., Kvilinskyi, O., Fasiecka, O. and Miskiewicz, R. 2017. Energy security in Regional Policy in Wielkopolska region of Poland. Ekonomia i Środowisko $\mathrm{nr} 2$ (61).

PAJĄK, K. ed. 2016. Low-emission economy and its impact on the economic development of Wielkopolska (Gospodarka niskoemisyjna i jej wpływ na rozwój gospodarczy Wielkopolski). Wydawnictwo Naukowe PWN, Warszawa (in Polish).

PMI 2017. Agile Practice Guide Bundle (Pmbok Guide) Paperback - September 22, 2017 by Project Management Institute, p. 122.

RUTKOWSKI, L. 2012. Artificial intelligence methods and techniques (Metody i techniki sztucznej inteligencji). Wydawnictwo Naukowe PWN, Warszawa, wyd. 2 zmienione, 452 pp. (in Polish).

SKRZYPEK, E. 2007. Role of economic efficiency in shaping business success (Efektywność ekonomiczna jako ważny czynnik sukcesu organizacji). [In:] Efektywność - konceptualizacja i uwarunkowania, T. Dudycz, G. Osbert-Pociecha i B. Brycz (red.), Prace Naukowe Uniwersytetu Ekonomicznego we Wrocławiu", nr 262, Wydawnictwo UE we Wrocławiu, Wrocław, 23 pp. (in Polish).

SzcZepańsKa-Woszczyna, K. and Kurowska-Pysz, J. 2016. Sustainable business development through leadership in SMEs. Ekonomia i Zarządzanie 8(3), 14 pp.

TARAFDAR et al. 2017 - TARAFDAR, M., BEATH, C.M. and Ross, J.W. 2017. Enterprise Cognitive Computing Applications: Opportunities and Challenges. IT Professional Vol. 19, Is. 4, 12 pp.

WaLSH, T. 2018. Sztuczna Inteligencja (It's alive! Artificial Inteligence from logic piano to killer robots), PWN, Warszawa, $52 \mathrm{pp}$.

WILCZYŃSKI, R. 2014. Efficiency measurement and corporate goals (Pomiar efektywności a cele przedsiębiorstw). Zeszyty Naukowe Uniwersytetu Szczecińskiego nr 66, Efektywność inwestycji i wycena przedsiębiorstw, pp. 547-558 (in Polish).

WrzoseK, S. 2005. The signification of the economic efficiency in the companies decisions processing (Znaczenie efektywności ekonomicznej $w$ procesach decyzyjnych przedsiębiorstw) [In:] Dudycz T. (red.), Efektywność - rozważania nad istota i pomiarem, Prace Naukowe AE we Wrocławiu nr 1060, Wrocław. www.wprost.pl, 459 pp.

ZAMASZ, K. 2015. Economic efficiency of an energy company in the conditions of introducing the capacity market (Efektywność ekonomiczna przedsiębiorstwa energetycznego w warunkach wprowadzenia rynku mocy). Wydawnictwo Naukowe PWN, Warszawa, p. 18 (in Polish).

ZAMASZ, K. 2019. Economic efficiency of a power company after the implementation of the capacity market, PWN, Warszawa, p. 29. 
Grzegorz KINELSKI

\title{
Główne czynniki skutecznego zarządzania projektami w aspekcie efektywności przedsiębiorstw energetycznych w środowisku gospodarki cyfrowej
}

\begin{abstract}
Streszczenie
Obecnie mówi się, że Przemysł 4.0 to czwarta rewolucja przemysłowa. Podobnie jak poprzednie, ma również zdolność przekształcania gospodarek, miejsc pracy i społeczeństw. Nasze oczekiwania zmieniają się wraz z szybkością uzyskiwania odpowiedzi na zadawane pytania. Odbywa się to poprzez wprowadzanie nowych technologii i procesów. To szansa dla polskich uczestników lokalnych rynków ciepła, czy też uczestników rynku mocy czy energii, którzy stoją obecnie w obliczu głębokich zmian i inwestycji wymuszonych m.in. konkluzjami BAT. Takie megaprocesy, jak cyfryzacja, automatyzacja, sztuczna inteligencja, IoT, uczenie maszynowe, coraz częściej przenikają do świata i biznesu. Minęło ponad 200 lat od pierwszej rewolucji przemysłowej, jaką było zastosowanie silnika parowego, a wymagania dotyczące testowania wydajności przedsiębiorstw uległy zmianie, same zaś przedsiębiorstwa zmieniają się bardzo szybko. Podstawowe mierniki efektywności stosowane w danym sektorze często wynikają ze specyfiki sektora i stopnia jego rozwoju w skali makroekonomicznej. Dlatego warto umieścić firmę energetyczną w takim otoczeniu i przedstawić jej rolę w lepszym dopasowaniu do stosowanych instrumentów. Z powyższym wiąże się również zwiększona sprawozdawczość i konieczność stosowania dodatkowych środków ewaluacyjnych, np. efektywność poszczególnych projektów. Warto zatem przeanalizować dostępną literaturę w tym zakresie oraz dostępne i zastosowane w niej mierniki efektywności, które pomogą w ocenie skuteczności zarządzania pomimo zawirowań politycznych i regulacyjnych, a także pomogą nam wykorzystać szanse, jakie niesie ze sobą czwarta rewolucja przemysłowa.
\end{abstract}

SŁowA KLUCZOWE: zarządzanie projektami, efektywność ekonomiczna, gospodarka cyfrowa, efektywność energetyczna 
